\title{
A pituitary POU domain protein, Pit-1, activates both growth hormone and prolactin promoters transcriptionally
}

\author{
Harry J. Mangalam, ${ }^{1}$ Vivian R. Albert, ${ }^{1}$ Holly A. Ingraham, ${ }^{1,2}$ Michael Kapiloff, ${ }^{1}$ Laura Wilson, ${ }^{1}$ \\ Charles Nelson, ${ }^{1,2}$ Harry Elsholtz, ${ }^{1,2}$ and Michael G. Rosenfeld ${ }^{1,2}$ \\ ${ }^{1}$ Eukaryotic Regulatory Biology Program and Center for Molecular Genetics, School of Medicine, M013, University of \\ California-San Diego, La Jolla, California 92093 USA; ${ }^{2}$ Howard Hughes Medical Institute, University of California, San \\ Diego, M013, La Jolla, California 92093 USA
}

\begin{abstract}
The anterior pituitary gland provides a model for investigating the molecular basis for the appearance of phenotypically distinct cell types within an organ, a central question in development. The rat prolactin and growth hormone genes are expressed selectively in distinct cell types (lactotrophs and somatotrophs, respectively) of the anterior pituitary gland, reflecting differential mechanisms of gene activation or restriction, as a result of the interactions of multiple factors binding to these genes. We find that when the pituitaryspecific 33-kD transcription factor Pit-1, expressed normally in both lactotrophs and somatotrophs, is expressed in either the heterologous HeLa cell line or in bacteria, it binds to and activates transcription from both growth hormone and prolactin promoters in vitro at levels even 10-fold lower than those normally present in pituitary cells. This suggests that a single factor, Pit-1, may be capable of activating the expression of two genes that define different anterior pituitary cell phenotypes. Because a putative lactotroph cell line (235-1) that does not express the growth hormone gene, but only the prolactin gene, appears to contain high levels of functional Pit-1, a mechanism selectively preventing growth hormone gene expression may, in part, account for the lactotroph phenotype.
\end{abstract}

[Key Words: Pit-1; growth hormone; prolactin; POU homeo domain]

Received April 19, 1989; revised version accepted May 23, 1989.

The hierarchical activation of regulatory genes appears to be responsible for the temporal and spatial patterns of gene expression required for normal development (Gehring 1987; Scott and Carroll 1987). A number of Drosophila genes that regulate such pattern development contain a conserved 60-amino-acid sequence referred to as the homeo domain (McGinnis et al. 1984; Manley and Levine 1985; Gehring 1987; Levine and Hoey 1988), and proteins containing this putative DNAbinding domain also have been identified in yeast, worms, and vertebrates (Carrasco et al. 1984; Shephard et al. 1984; Colberg-Poley et al. 1985; Awgulewitsch et al. 1986). Following the initial pattern formation that takes place early in embryonic development, it has been proposed that tissue-specific factors activate the characteristic genes that define the cellular phenotype (e.g., Walker et al. 1983; Nelson et al. 1986, 1988; Sen and Baltimore 1986; Staudt et al. 1986; Bodner and Karin 1987; Hammer et al. 1987; Costa et al. 1988.

We use the anterior pituitary gland, derived from the embryonic ectoderm of Rathke's pouch, as a model to study cellular differentiation. This structure differentiates into five distinct cell types, distinguished on the basis of the secreted hormone. The two most prevalent pituitary cell types are the growth hormone-producing somatotrophs and prolactin-producing lactotrophs. The evolutionary relatedness of the growth hormone (GH) and prolactin (PRL) genes (Cooke et al. 1981) and their transient coexpression during development /Chatelain et al. 1979; Watanabe and Daikoku 1979; Hoeffler et al. 1985) suggest that similar mechanisms might be expected to control activation of the two genes. Both the rat PRL promoter $(-422$ to +33$)$ and rat GH promoter $(-180$ to +8$)$ direct cell-specific expression in vitro (Nelson et al. 1986, 1988; Bodner and Karin 1987; Cao et al. 1987; Guitierrez-Hartmann et al. 1987; Lufkin and Bancroft 1987; West et al. 1987; Ye and Samuels 1987) and in transgenic mice (Behringer et al. 1988; Lira et al. 1988; Crenshaw et al. 1989) and therefore possess sufficient information to direct cell specificity.

On the basis of competition experiments involving DNase I footprinting and mutational analyses (Nelson et al. 1988), we proposed that several related sequences in the PRL and GH promoters bound either common or functionally related, pituitary-specific, transcription factors termed Pit-1 (summarized in Fig. 1A). On the basis of the characterization of a candidate protein, we were able to clone a cDNA from a rat pituitary library, as a result of the ability of the encoded $33-\mathrm{kD}$ protein to bind to sequences of both PRL and GH genes. We pro- 
posed that this protein represented Pit-1 (Ingraham et al. 1988). This protein was notable not only for its transcriptional effects and pituitary-restricted expression, but also for its structure. At the carboxyl terminus was a stretch of 60 amino acids with homology to the homeo domain present in many Drosophila developmental proteins (Gehring 1987). Toward the amino terminus was a 76-amino-acid region that was homologous to three other proteins cloned recently, Oct-1, Oct-2, and unc-86 (Herr et al. 1988). The human transcription factors Oct-1 (Sive and Roeder 1986; Sturm et al. 1988) and Oct-2 (Clerc et al. 1988; Ko et al. 1988; Muller et al. 1988) bind to the octameric recognition site (ATTTGCAT) of target genes, which differs from that of Pit-1 ( ${ }_{\mathrm{T}} \mathrm{TATNCAT}$ ) by only a single base pair (Nelson et al. 1988). Oct-1 is expressed widely, whereas Oct- 2 appears to be more restricted, being expressed in the B lymphocytes and also in certain areas of the brain (He et al. 1989). unc-86 is a Caenorhabditis elegans protein that was detected by the effects of its mutation, which resulted in alterations in neuronal cell development (Chalfie et al. 1981; Finney et al. 1988).

It is of great interest to determine the binding and trans-activation proclivities of Pit-1, as it is one of the first described mammalian POU-homeo domain proteins expressed in an organ that contained distinct cell types. Given our previous data about its binding preferences and the evidence that Pit-1 is expressed in both lactotrophs and somatotrophs (Bodner et al. 1988; Ingraham et al. 1988), we predicted that Pit-1 would be involved in the transcriptional activation of the similarly restricted GH and PRL genes. This supposition was supported initially by transient cotransfection studies in HeLa cells, indicating that the Pit-1 cDNA gene product could increase the expression of reporter genes directed by the promoters of either the PRL or GH genes. However, on the basis of experiments using a bacterial fusion protein that contained a portion of the cloned gene product GHF-1 (identical to Pit-1) and partially purified GHF-1 from pituitary cells, it has been suggested that GHF-l binds to and activates exclusively the GH, but not the PRL, promoter (Bodner et al. 1988; Castrillo et al. 1989). This proposed selectivity of target gene would be in contrast to the actions of many of the Drosophila homeo box proteins, which appear to activate sets of genes combinatorially to achieve their dramatic developmental effects (Gehring 1987; Desplan et al. 1988; Hoey and Levine 1988; Levine and Hoey 1988). The critical issue, then, is whether Pit-1 can or cannot activate PRL or GH gene expression at physiological levels of expression. In this paper we report that when the entire Pit-1 protein is expressed in both eukaryotic and bacterial systems, it binds effectively to both the GH and PRL genes and indeed preferentially activates transcription of the PRL promoter at physiological concentrations. We observed this in both in vitro systems and in a heterologous cell line. We present evidence for an additional mechanism required to establish the mature lactotroph and somatotroph phenotypes.

\section{Results}

To initiate studies regarding PRL and GH transcriptional activation, native Pit-1 from GC cell extracts was purified by combining conventional separation techniques with DNA-affinity chromatography (Kadonaga and Tjian 1986). Activity was assessed by DNase I footprint (Galas and Schmitz 1978), Southwestern blot (Bowen et al. 1980; Jack et al. 1982), and in vitro transcription assays (Nelson et al. 1988), using both the PRL and GH promoters. Phosphocellulose chromatography effectively separated Pit-1 activity from a second factor (Prl1) that bound to the PRL promoter at -106 to -83 (data not shown). Following hydroxyl-apatite column fractionation (see Methods), the Pit-1 activity was applied to a DNA affinity column made from multimers of the rat GH promoter element GH1 (see Fig. 1A). The column was developed with a linear $\mathrm{KCl}$ gradient; Pit-1 activity eluted between 250 and $450 \mathrm{~mm}$. Size separation of gradient fractions by SDS-polyacrylamide gel electrophoresis (SDS-PAGE; Laemmli 1970), followed by silver stain (Merril et al. 1984), revealed a prominent $33+31$ $\mathrm{kD}$ doublet, as well as an additional $47-\mathrm{kD}$ protein (Fig. 1B). The lower band of the doublet could formally be a different gene product, but is more likely to represent a modified form of the $33-\mathrm{kD}$ protein. Similar doublets have been observed using extracts from pituitary cell lines, with slight variations in molecular weights (Bodner et al. 1988; Cao et al. 1988; Ingraham et al. 1988).

When affinity-purified material was evaluated by a Southwestern blot, specific DNA binding was restricted exclusively to either the $33-\mathrm{kD}$ protein or to the $33+31-\mathrm{kD}$ doublet (Fig. 1C). Similarly, the purified protein was able to stimulate transcription from a series of both PRL and GH promoter constructs, when added to an otherwise incompetent HeLa cell nuclear extract (Fig. $1 D$ ), and the peak of transcriptional activity also fractionated with the $33-\mathrm{kD}$ protein (data not shown). Affinity column fractions were analyzed in DNase I footprinting reactions with both the PRL and the GH promoters. On both, each of the putative Pit-1-binding sites was protected by the affinity column-purified Pit-1 protein (Fig. 2A,B). The final purification of Pit-1 was judged to be at least 4000 -fold, on the basis of the amount of protein required to protect the binding sequence from digestion with DNase I.

Because transient transfection analyses could generate misleading results on the basis of overexpression of the encoded trans-acting factor, the Pit-1 cDNA was incorporated into an SV40-based expression vector (Fig. 3A; Lin et al. 1987; Nelson et al. 1988) and transfected stably into $\mathrm{HeLa}$ cells. These cells $\left(\mathrm{HeLa} / \mathrm{Pit}^{+}{ }^{+}\right)$expressed a $33-\mathrm{kD}$ protein that comigrated with the phosphocellulose- and affinity-purified protein from GC extracts, but at levels $<10 \%$ that in GC cells, as assayed by Southwestern blot (Fig. 2C) or gel-shift (Fried and Crothers 1983; data not shown), and permitted evaluation of whether Pit-1 would activate GH or PRL gene expression at these low levels. Transfection of these HeLa/ 

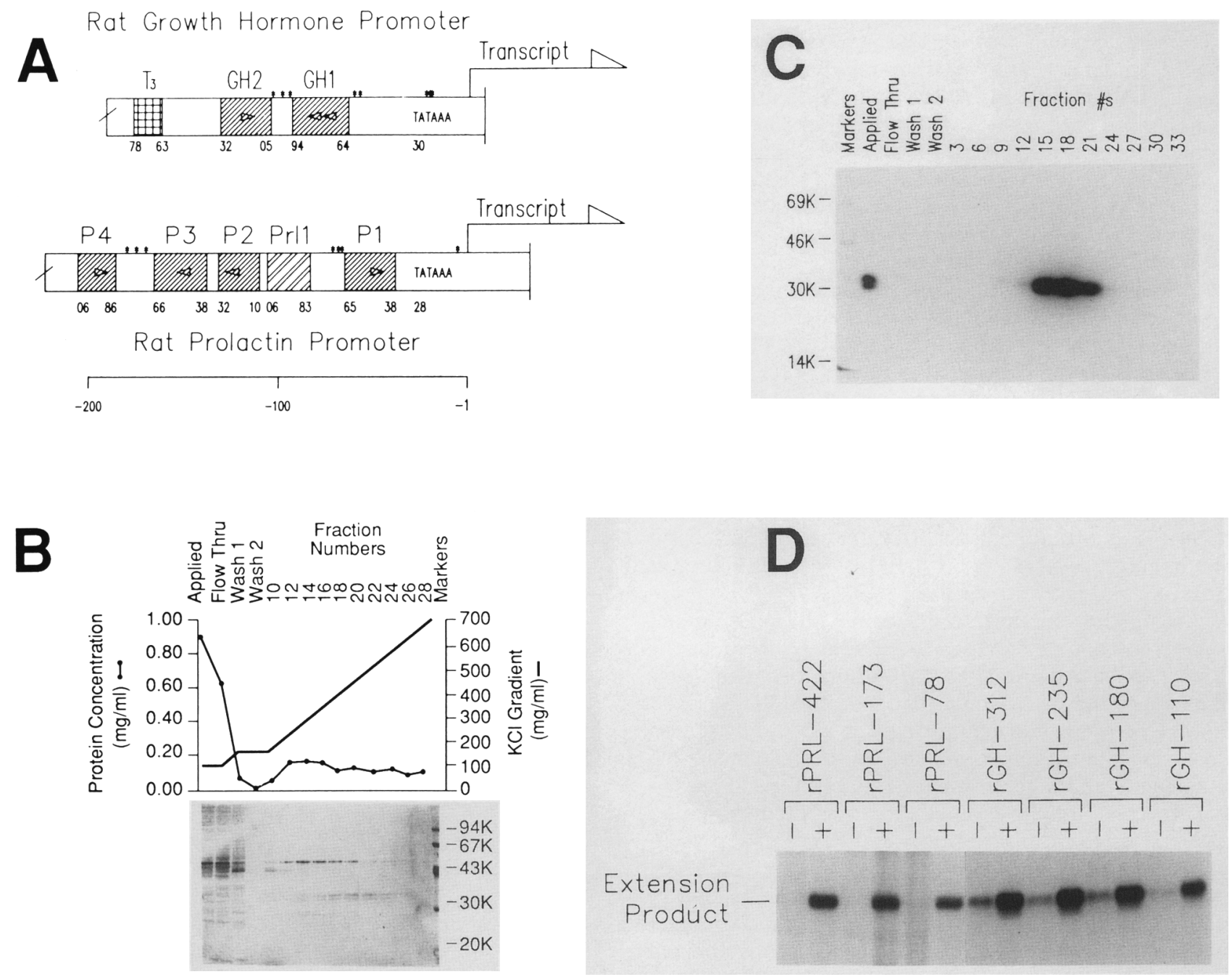

Figure 1. (A) The rat GH and PRL promoters are shown to scale. Regions protected from DNase I digestion following incubation with GC nuclear extracts are hatched. Asterisks indicate DNase I hypersensitive sites in the presence of nuclear extract. The similarly hatched boxes (GH1, GH2, P1-P4) designate those elements proposed to bind Pit-1. [Site Prll is referred to as $2 \mathrm{P}$ by Bodner et al. (1988) and Castrillo et al. (1989), who combine the P2 and P3 sites to a single site referred to as $3 P$ ' $\triangle$ ' $=$ TATNCAT, the Pit-1 consensus binding sequence.] $\mathrm{T}_{3}$ on the $\mathrm{GH}$ promoter is a reported thyroid hormone response element (Glass et al. 1987). The element labeled Prll has not been characterized extensively, but appears to be PRL-specific. (B) Protein (1.8 mg) from the flowthrough of the hydroxyl-apatite column was applied to $0.9 \mathrm{ml}$ of affinity column resin (multimers of the GH1 site). After two 1-ml washes, the bound protein was eluted with a linear gradient of $\mathrm{KCl}$ to $700 \mathrm{mM}$ in PC buffer (top). (Bottom) $100 \mu \mathrm{l}$ of each fraction was concentrated by acetone precipitation, analyzed by SDS-PAGE, and silver-stained (Merril et al. 1984). Lanes: (Applied) $1 \mu \mathrm{g}$ of the hydroxyl-apatite flowthrough; (Flow Thru) $1 \mu \mathrm{g}$ of the affinity-column flowthrough; (Wash 1 and Wash 2) $100 \mu$ l of the respective washes, processed as per the fractions. $(C)$ The indicated fractions were concentrated by acetone precipitation, size-fractionated by SDS-PAGE, transferred to nitrocellulose, and incubated with radiolabeled ${ }^{-173 .+}+33 \mathrm{PRL}$ promoter and $3 \mu \mathrm{g} / \mathrm{ml}$ of salmon sperm DNA as a nonspecific competitor in binding buffer (see Methods). Lanes: (Markers) Protein standards; (Applied) $2 \mu$ l of the hydroxyl-apatite column flowthrough; (Flow Thru) $10 \mu \mathrm{l}$ of the affinity-column flowthrough; (Wash 1 and Wash 2) $5 \mu \mathrm{l}$ of the $150 \mathrm{mM} \mathrm{KCl} \mathrm{column} \mathrm{washes;} \mathrm{(Fraction} \mathrm{\# s)} 5 \mu \mathrm{l}$ of each fraction. $(D)$ In vitro transcription with affinity column-purified Pit-1. Transcription from PRL and GH promoter-luciferase (De Wet et al. 1987) fusion genes is shown, as indicated, using $10 \mu \mathrm{l}(100 \mu \mathrm{g})$ of HeLa cell nuclear extract alone $(-)$ or supplemented with $5 \mu \mathrm{l}$ of affinity column fraction $21\left(+1\right.$. Correctly initiated transcripts were visualized by primer extension using ${ }^{32} \mathrm{P}-\mathrm{labeled}$ luciferase primers.

Pitl ${ }^{+}$cells with GH fusion genes that contained 180 or $110 \mathrm{bp}$ of $5^{\prime}$-flanking information, or even three copies of the GHl element fused to a minimal promoter $\left({ }^{-36 . .+33} \mathrm{PRL}\right)$ resulted in levels of expression 20 - to $100-$ fold greater than those observed when the same constructs were transfected into the parental cell line (Fig.
3B). Activation of transfected PRL promoter fusion genes in the $\mathrm{HeLa} / \mathrm{Pitl}{ }^{+}$cells was consistently more dramatic, reaching levels $>200$-fold higher than those observed in untransfected HeLa cells (Fig. 3B). In contrast, a series of other promoters [e.g., the Rous sarcoma virus (RSV) promoter (Gorman et al. 1982b) and the glucocorticoid (Ya- 


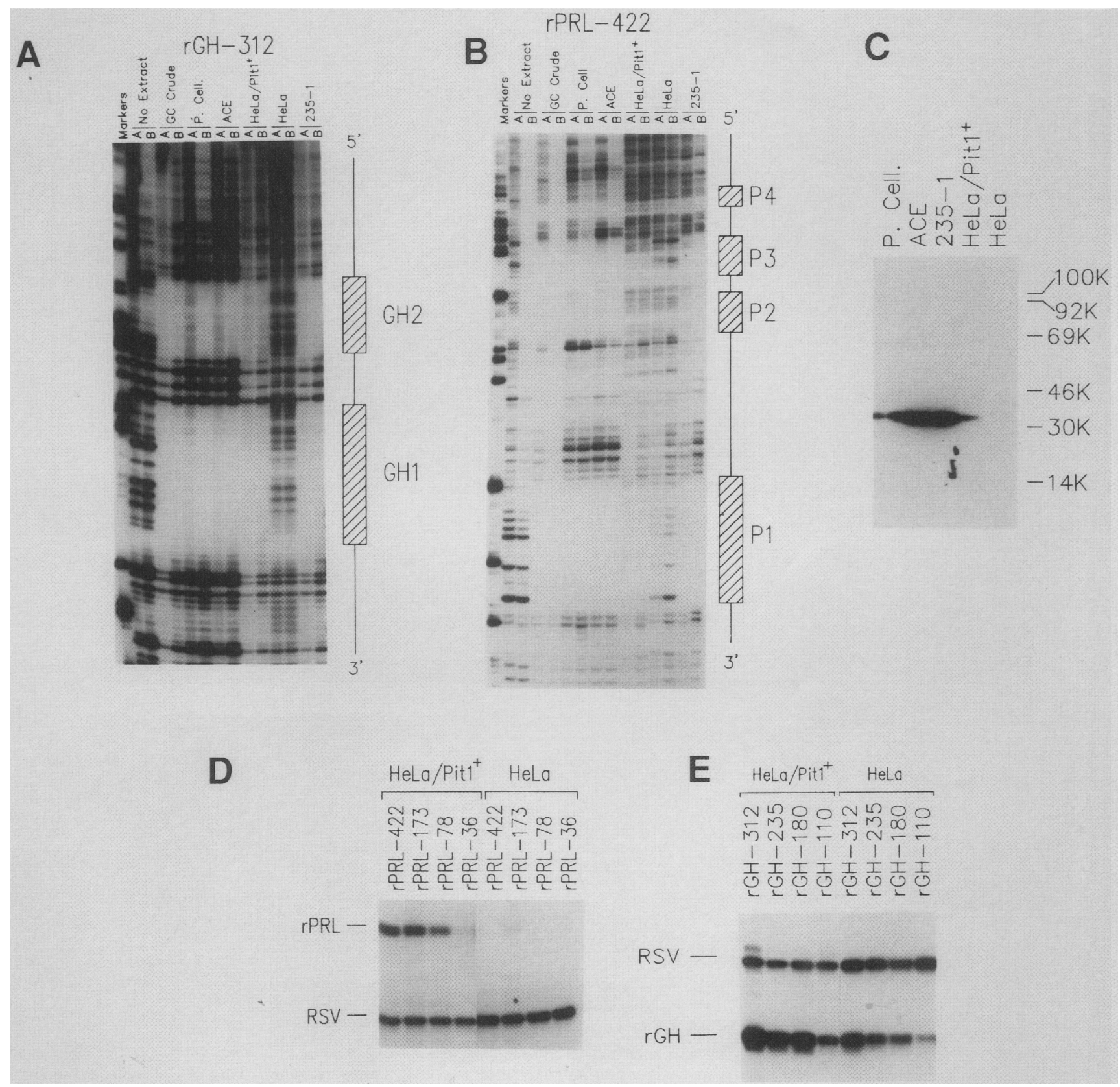

Figure 2. $(A, B)$ The DNase I footprints generated by crude nuclear extracts, as well as PC and affinity column-purified fractions, are compared to those generated by the extracts from the HeLa/Pitl ${ }^{+}$cells. Lanes [for both the ${ }^{-312 . .+8} \mathrm{GH}(\mathrm{labeled}$ at $+8 ; A)$ and the -422.. ${ }^{33} \mathrm{PRL}$ (labeled at +33 ; B) promoters]: (Markers) ' $\mathrm{G}^{\prime}$ reactions; (No Extract) control ladder; (GC Crude) $40 \mu \mathrm{g}$ of GC crude nuclear extract; $(P$. Cell $) 5 \mu \mathrm{g}$ of phosphocellulose column fraction $28 ;(A C E) 150 \mathrm{ng}$ of affinity column, fraction $21 ;\left(\mathrm{HeLa} / \mathrm{Pit}^{+}\right) 120$ $\mu \mathrm{g}$ of $\mathrm{HeLa} / \mathrm{Pit}^{+}{ }^{+}$crude nuclear extract; $(\mathrm{HeLa}) 120 \mu \mathrm{g}$ of HeLa cell crude nuclear extract; (235-1) $50 \mu \mathrm{g}$ of 235-1 lactotroph crude nuclear extract. $(C)$ The indicated samples were treated as in Fig. 1C and probed with ${ }^{32} \mathrm{P}$-labeled ligated multimers of PRL P1 site in the presence of $3 \mu \mathrm{g}$ of salmon sperm DNA. Lanes: $(P$. Cell) $5 \mu \mathrm{g}$ of a PC column fraction that contained the peak of Pit-1 activity; $(A C E) 100 \mathrm{ng}$ of affinity column eluate, fraction 21 ; (235-1) $100 \mu \mathrm{g}$ of 235-1 (lactotroph) cell crude nuclear extract $;\left(\mathrm{HeLa} / \mathrm{Pit1}^{+} \mid 200 \mu \mathrm{g}\right.$ of $\mathrm{HeLa} / \mathrm{Pit} \mathrm{l}^{+}$crude nuclear extract; $(\mathrm{HeLa}) 200 \mu \mathrm{g}$ of HeLa cell crude nuclear extract. $(D, E)$ Transcription from templates that contained PRL $(D)$ and GH $(E)$ promoter constructs in $20 \mu \mathrm{l}(200 \mu \mathrm{g})$ of HeLa cell nuclear extract or $40 \mu \mathrm{l}(200 \mu \mathrm{g})$ of $\mathrm{HeLa} / \mathrm{Pit} \mathrm{l}^{+}$ nuclear extract as indicated. Transcription units are designated by the base to which the promoter extends at the $5^{\prime}$ border.

mamoto 1985) or cAMP response elements (Montminy et al. 1986) linked to the ${ }^{-36 . .+33}$ PRL minimal promoter] exhibited less than a twofold increase in expression in HeLa/Pitl ${ }^{+}$cell lines (data not shown). Figure 2A shows that the Hela/Pit $1^{+}$nuclear extract generated footprints on the high-affinity GH1 and GH2 sites of the GH promoter that were indistinguishable from those made by GC extracts. When the HeLa/Pit ${ }^{+}$extract was incu- 


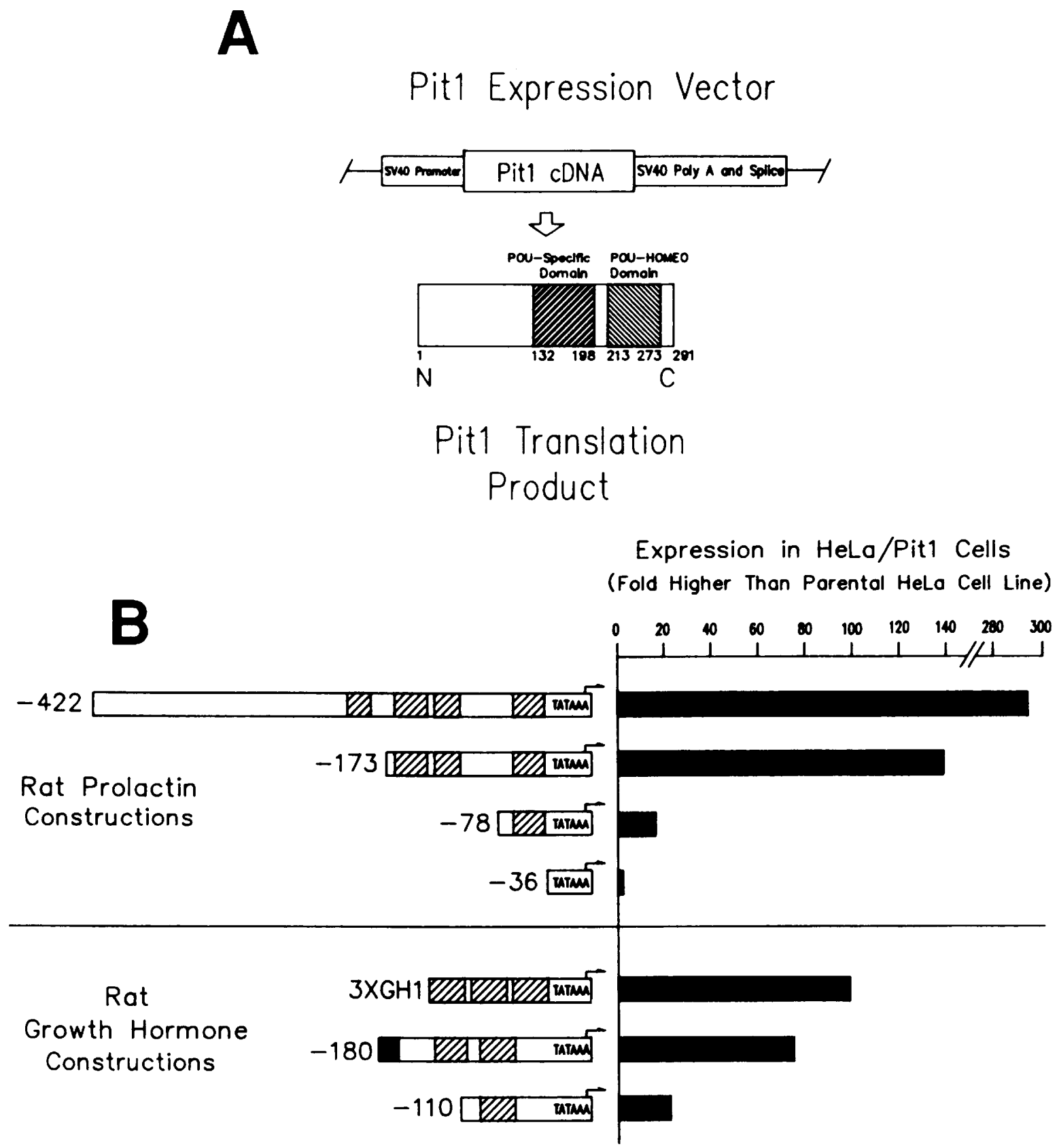

Figure 3. (A) The cDNA encoding Pit-1 is shown incorporated into the expression vector, which uses the SV40 enhancer/promoter and polyadenylation and splice site (top); the 291-amino-acid translation product, showing the positions of the POU-specific domain and the POU-homeo domain (bottom). $(B)$ Hela cells transfected stably with the Pit-l expression vector $\left(\mathrm{HeLa} / \mathrm{Pitl}^{+} \mid\right.$were transfected transiently with $10 \mu \mathrm{g}$ of plasmid that contained either the PRL or the GH promoter variants (left) fused to the firefly luciferase gene. Luciferase activity in $50 \mu \mathrm{g}$ of the cell lysate was measured and compared to the value obtained when the same plasmid was transfected into the parental HeLa cell line (which lacked Pit-1). Values shown represent the mean, determined from five (PRL constructs) or four (GH constructs) experiments.

bated with the PRL promoter (Fig. 2B), the higher-affinity sites P1 and P3 were protected (P3 incompletely), but the lower-affinity sites P2 and P4 were not. The failure to protect the low-affinity sites apparently reflects the low levels of expression of Pit-1 in the HeLa/ Pit ${ }^{+}$cells (Fig. 2C) and is consistent with a higher affinity of Pit-1 for the P1 and GH1 and GH2 sites. Simi- larly, nuclear extracts from these cells stimulated both GH and PRL transcription to levels comparable to those from crude GC nuclear extracts and HeLa cell extracts supplemented with purified Pit-1 (Fig. 2D,E).

In the absence of Pit-1, the GH promoter variants are somewhat 'leaky' in this assay, probably as a result of other factors that can activate the promoter (consensus 
AP2-, AP3-, and T3-binding sites are located within the part of the promoter that we used). However, competition with oligonucleotides encoding a Pit-1-binding site (GHI) demonstrated that the activation of the GH promoter in these extracts was due to binding of Pit-1 to the cell-specific, cis-active elements (Fig. 5D). Therefore, despite slight differences in affinity for Pit-1, both genes were activated by Pit-1 levels well below those present in pituitary cell lines.

To establish the relative threshold of PRL and GH gene activation, Pit-1 cDNA was placed into a transcription unit that permitted effective expression in bacteria (Studier et al. 1986; Rosenberg et al. 1987). Bacterially expressed Pit-1 (Pit-1 $1^{\text {bac}}$ ) was able to protect the same sites on the GH and PRL genes as Pit-1 isolated from GC cells (Fig. 4A-F), with a slightly higher affinity for the $\mathrm{GH}$ sequences than for those of PRL. In contrast, a bacterial trpE-fusion protein that contained a partial GHF-1 coding sequence was reported to bind solely to the the GH but not the PRL promoter sequences (Bodner et al. 1988); however, it did not contain the POU-specific region required for high-affinity, specific DNA binding (Sturm and Herr 1988; H.A. Ingraham and M.G. Rosenfeld, unpubl.). By Southwestern blot analysis (Fig. 6C), Pit-1 $1^{\text {bac }}$ migrated as a single band of $\sim 33 \mathrm{kD}$, equal to the size of the upper band of the doublet seen in GC and 235-1 cells. As shown in Figure 5, A, B, and C, bacterially expressed Pit-1 increased transcription of both PRL and GH fusion genes greatly when added to HeLa and other heterologous cell nuclear extracts. Titration curves show similar half-maximal levels of Pit-1 for activation of PRL and GH promoters; a series of other promoters are inactive at these levels of Pit- 1 , including RSV and the minimal PRL promoter $(-36$ to +33$)$, alone or in combination with oligonucleotides that contained the thyroid hormone response element (Glass et al. 1987; data not shown) or the cAMP response element (Montminy et al. 1986) and a mutation of PRL site P1 that does not bind Pit-1 well (P1 $\mu$; Fig. 5A). Also, Pit- $1^{\text {bac }}$ stimulated the transcription of the PRL distal enhancer in vitro when placed $5^{\prime}$ of the minimal PRL promoter $(-36$ to +33$)$ (Fig. 5C). Only when Pit- $1^{\text {bac }}$ was added at extremely high concentrations were small element-independent increases in transcription from some of these constructs, typically from the RSV and the $\mathrm{P} 1 \mu$ constructs (Fig. 5A), observed.

This parallel activation of both the PRL and GH genes is somewhat paradoxical, because these two genes are normally expressed in different cell types. The 235-1 lactotroph cell line, which expresses the endogenous PRL but not the GH gene, offers an in vitro model in which to explore this conundrum. Transient transfection of a ${ }^{-235 . .+8} \mathrm{GH}$-luciferase (De Wet et al. 1987) fusion gene into 235-1 cells did not result in luciferase ex- pression at a detectable level, but a ${ }^{-422 .+33} \mathrm{PRL}-$ luciferase fusion gene was expressed at high levels (Fig. 6A) and primer extension analysis has confirmed correct cap site utilization from this construct (Nelson et al. 1988). Because of this differential gene activation, the presence of Pit-1 in 235-1 cells was evaluated by DNase I footprinting and binding analyses. As shown in Figures 2, A and $B$, and 4, A-F, 235-1 crude nuclear extracts protected the same sites on GH and PRL genes as did Pit-1 isolated from GC cells or Pit- ${ }^{\text {bac }}$. RNase protection assays confirmed the presence of high levels of Pit-1 mRNA in 235-1 cells (Fig. 6B) and Southwestern blot analysis also confirmed the presence of the $33+31-\mathrm{kD}$ doublet in 235-1 cells at approximately the same levels found in GC cells (Fig. 6C). Specific binding of an antibody against the carboxyl terminus of Pit-1 to a Western blot also confirmed the expression of Pit-1 in 235-1 nuclear extracts (data not shown). Although 235-1 cells were unable to express $\mathrm{GH}$ fusion genes despite the presence of Pit-1, in vitro transcription assays were performed using 235-1 nuclear extracts. Surprisingly, a series of GH fusion genes were transcribed effectively in 235-1 nuclear extracts (Fig. 6D) at levels comparable to those observed with GC nuclear extracts. This transcription was decreased by competing oligonucleotides that contained the GH1 site (Fig. 5D), indicating that transcription was Pit-1 dependent.

\section{Discussion}

The combinatorial actions of transcription factors in determining gene expression are established clearly for both regulatory and developmental events. Therefore, it might be expected that the cell type-specific expression of genes in the anterior pituitary could involve the actions of multiple factors, some of which might actually act to enhance transcription of genes that are ultimately expressed in distinct cell types. In this context, the critical definition of a gene-specific positive transcription factor is its ability to bind to specific cis-acting elements and to activate gene transcription as a consequence of this binding. The concentration of a factor, the number of its binding sites, its relative affinity for the sites, and the topology of the sites relative to the sites of other factors will dictate the resultant pattern of gene activation.

On the basis of studies that were confined to footprinting analysis, Castrillo et al. (1989) concluded that Pit-1 (GHF-1) activates GH gene transcription selectively. On the basis of studies that were confined to footprinting analysis, with an incomplete bacterial fusion protein or a partially purified preparation, Castrillo et al. (1989) concluded that GHF-1 (Pit-1) activates GH

Figure 4. (See p. 952.) DNase I footprinting analysis of the GH promoter (end followed by asterisk is labeled; $A, D$ ), the PRL promoter $(B, E)$, and the PRL distal enhancer $(C, F)$, with increasing amounts of Pit-1-containing extracts. Lanes: (235-1) Crude nuclear extract from 235-1 lactotrophs; $(G C-P C)$ phosphocellulose-purified GC nuclear extract; $($ Bact-PC) phosphocellulose-purified Pit-1 expressed in bacteria. Numbers indicate the amount of protein added in micrograms. The sites are the same as those in Fig. $1 \mathrm{~A}$. $A, B$, and $C$ show titration curves with higher protein concentrations than those in $D, E$, and $F$. 


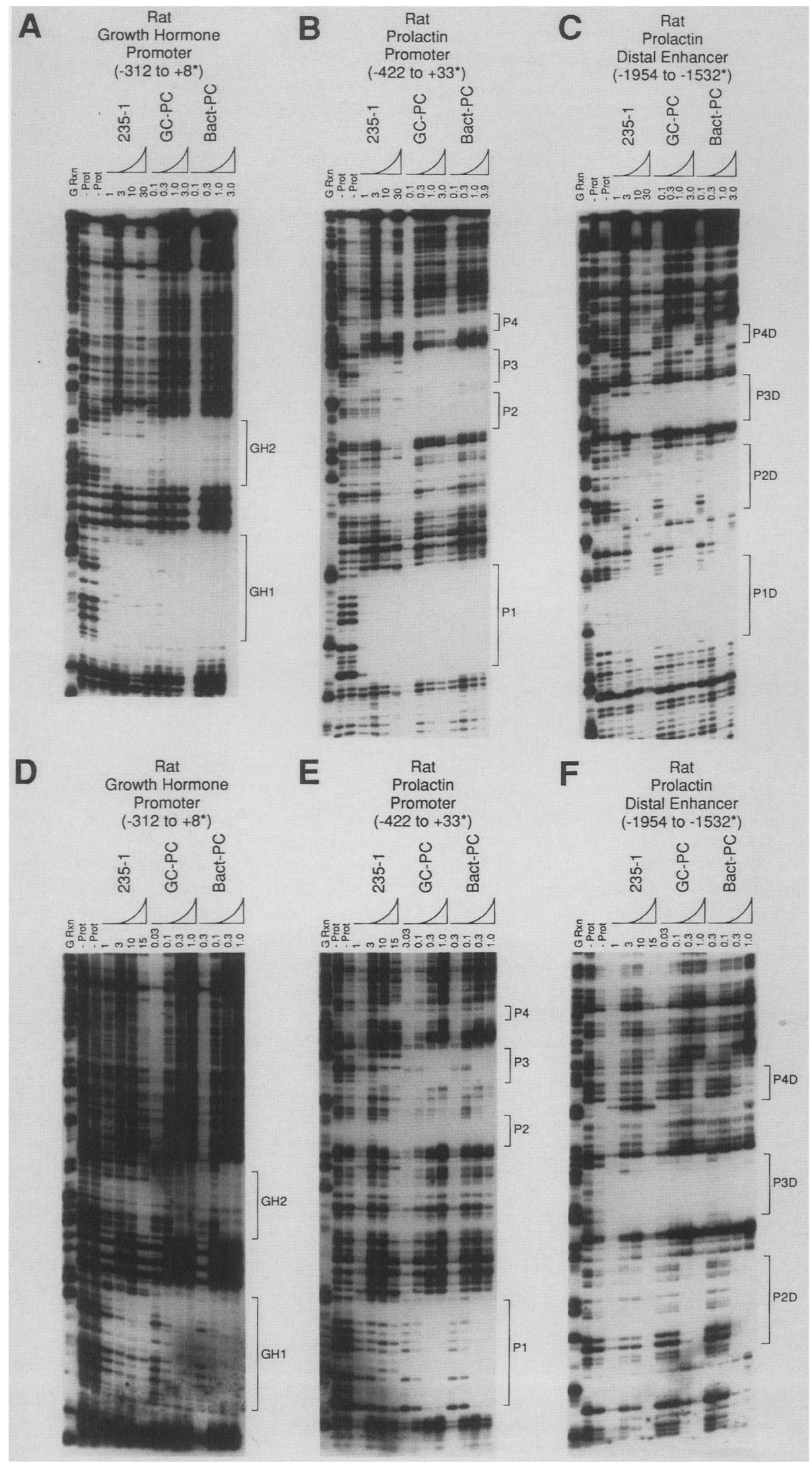

Figure 4. (See previous page for legend.) 


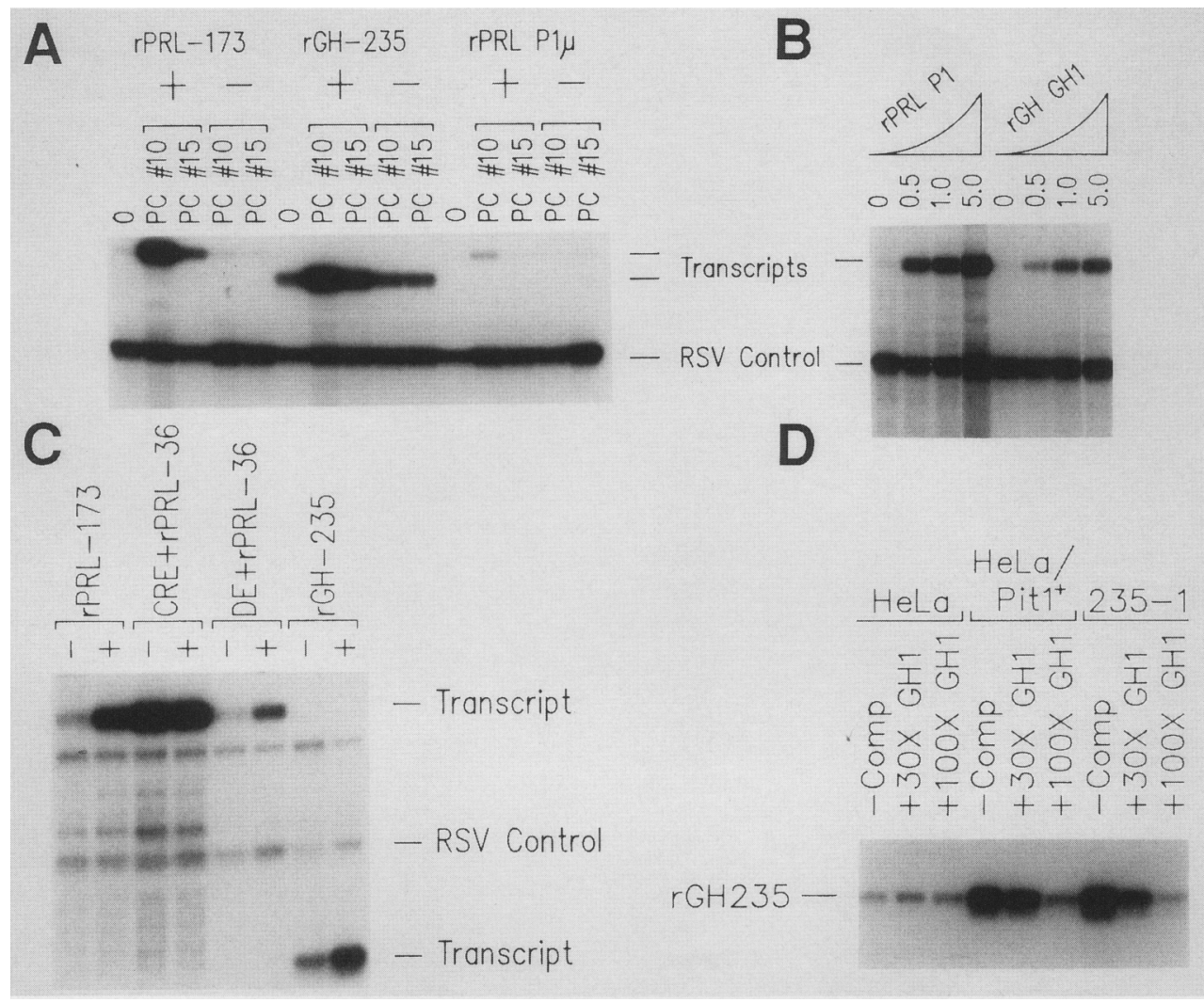

Figure 5. (A) In vitro transcription using bacterially expressed Pit-1 (Pit- ${ }^{\text {bac}}{ }^{\text {b }}$. Five microliters of the indicated fraction was added to transcription reactions with constructs that contained the $-173 . .+33$ PRL promoter (PRL-173), the ${ }^{-235 . .+8} \mathrm{GH}$ promoter (GH-235), or a mutation of the PRL site P1, which reduced binding of Pit-1 by $>100$-fold (PRL Pl $\mu$ ). The fractions are from a parallel PC column purification of extracts from bacteria either carrying $(+)$ or not carrying $(-)$ the Pit- 1 expression vector. $(B)$ In vitro transcription response with increasing amounts of Pit- $1^{\text {bac }}$. The indicated microliters of Pit-1 ${ }^{\text {bac }}$ from $A$, were added to $10 \mu \mathrm{l}(100 \mu \mathrm{g})$ of $\mathrm{HeLa}$ cell nuclear extract with a luciferase fusion gene that contained an oligonucleotide of either PRL site Pl or GH site GH1 fused 5' to the ${ }^{-36 .+33}$ PRL promoter. An RSV long terminal repeat (LTR) fusion gene also was included in each reaction as an internal control. (C) In vitro transcription of three constructs that contained Pit-1-binding sites [GH-235 and PRL-173 (Fig. 5A) and the -1954..-1532PRL distal enhancer fused to the ${ }^{-36 .+33}$ PRL promoter (DE + PRL-36)], as well as a construct that lacks one [the cAMP response element (Montminy et al. 1986) fused to the ${ }^{-36 .+33}$ PRL promoter (CRE + PRL-36)]. The reactions were carried out either without (-) or with $(+1$ the addition of $3 \mu \mathrm{l}$ of Pit-1 bac PC fraction 10 (see $A$ ) to $10 \mu \mathrm{l}$ S194 lymphocyte nuclear extract. The RSV LTR control is included also. $(D)$ Pit-1 dependence of transcription from the GH promoter in $\mathrm{HeLa}, \mathrm{HeLa} / \mathrm{Pit}{ }^{+}$, and 235-1 cell extracts. Lanes for each extract: $(-$ Comp $)$ The transcription from the ${ }^{-235 .+8} \mathrm{GH}$-chloramphenicol acetyltransferase (CAT) plasmid in the absence of competing DNA; $(+30 \times \mathrm{GH} 1)$ transcription in the presence of double-stranded oligonucleotides corresponding to the GH GHl site at 30 times the molar amount of template; $(+100 \times$ GH1) transcription corresponding to GH with GH1 at 100 times the amount of template.

gene transcription selectively. However, analysis of permanent transfectants expressing Pit-1 at a level 10-fold lower than physiological, both PRL and GH promoters were activated. Unexpectedly, fusion genes that contained the PRL promoter were activated much more effectively than those that contained the $\mathrm{GH}$ promoter under these conditions. In concert with these observations, we document that bacterially expressed intact Pit-1 binds specific cis-acting elements effectively in the rat PRL promoter. Thus, even though the two GH cisacting binding elements are among the highest Pit- 1 affinity sites, our data argue that the PRL proximal promoter sites can be occupied effectively at physiological concentrations of Pit-1. Both Castrillo et al. (1989) and Mangalam et al. (see Prll, Fig. 1A) find evidence of additional proteins that can bind to PRL promoter cis-acting elements; however, these proteins do not overlap totally in their footprinting patterns. These or additional proteins are likely to exert important functions in PRL gene expression.

Analysis of the putative 235-1 lactotroph cell line suggests that Pit-1 alone cannot be responsible for the restricted pattern of PRL and GH expression in mature lactotrophs and somatotrophs. Our data are consistent with either an inhibitory mechanism that prevents the actions of Pit-1 on the GH gene or the possibility that cell-specific expression of $\mathrm{GH}$ requires an additional positive activity that is absent in the 235-1 cells. It is likely that similar events restrict PRL gene expression in somatotrophs. Both mechanisms could involve the interaction of Pit-1 with additional proteins or simply the modification of Pit-1 (Jackson and Tjian 1988; Santoro et 
A
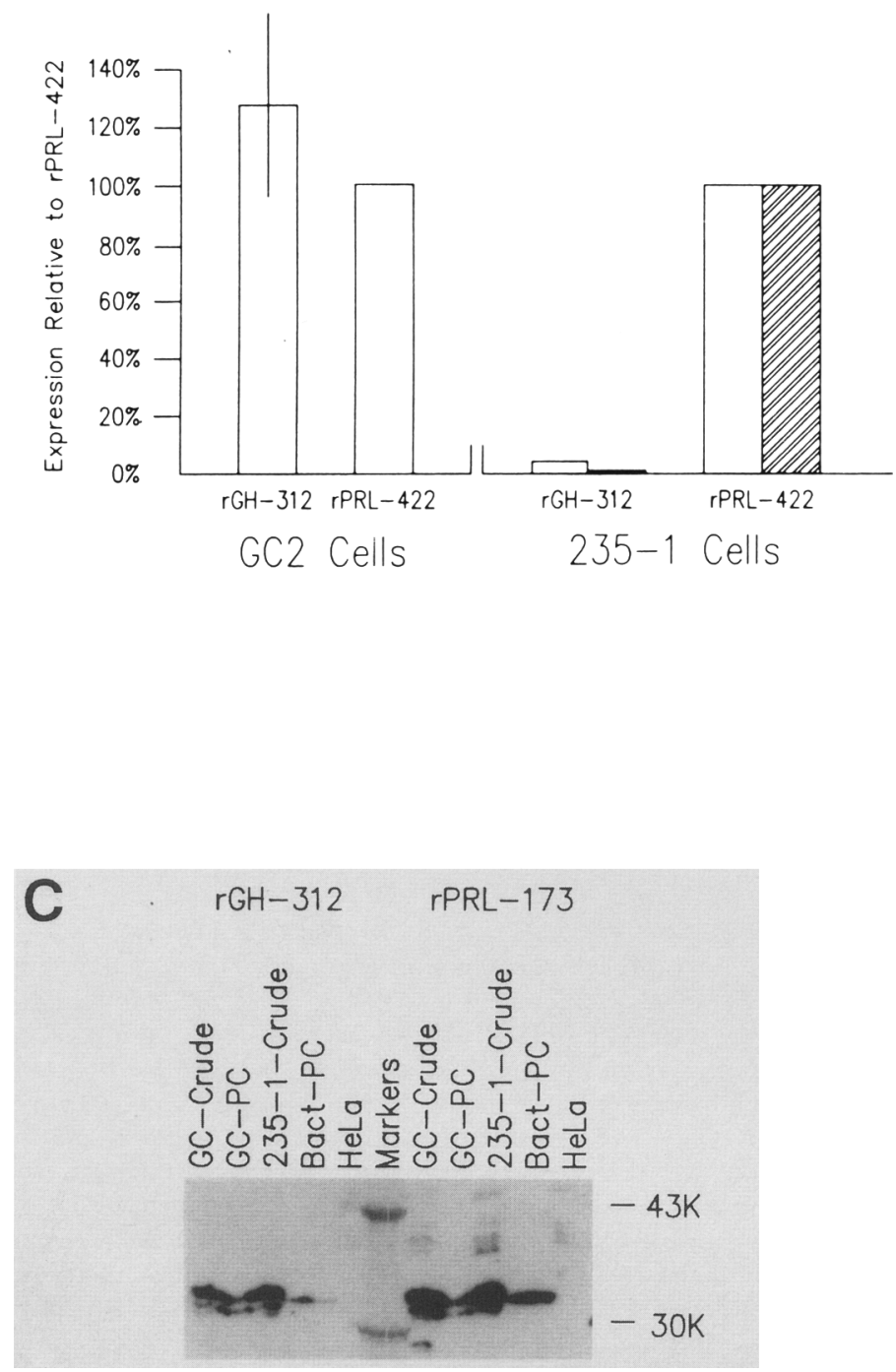
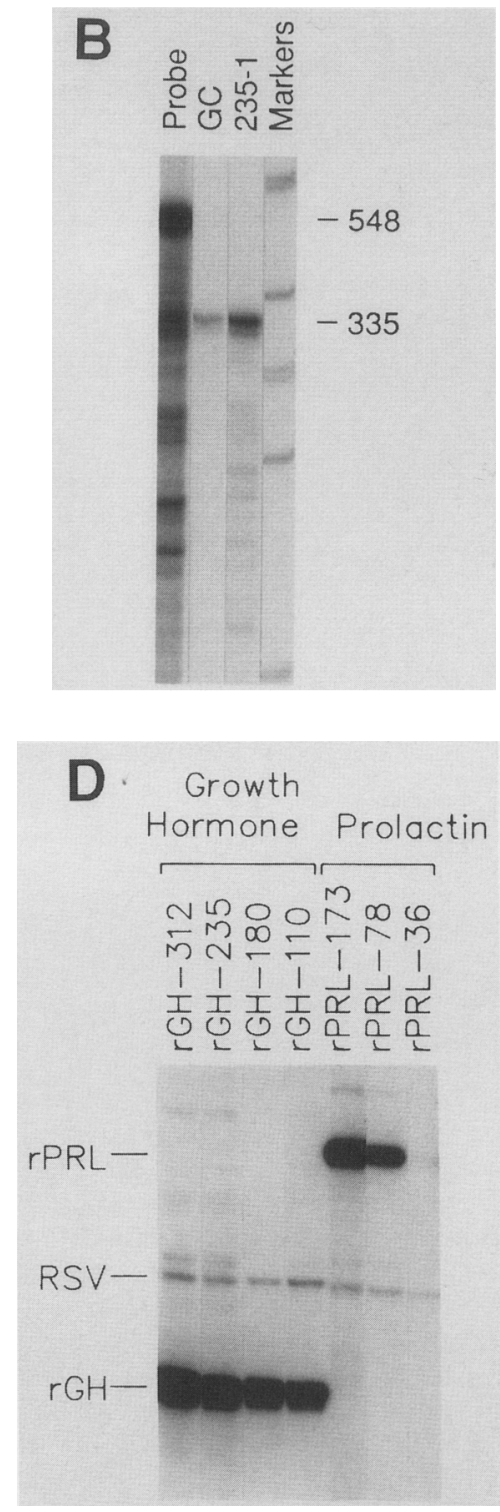

Figure 6. (A) Transient transfection of 235-1 lactotroph cells. Plasmids that contained either the GH or PRL promoters fused to the luciferase gene were transfected transiently into both GC and 235-1 cells, using the DEAE-dextran method (Gorman et al. 1982a). Fifty micrograms of cell lysate was analyzed for luciferase expression. (Left) ${ }^{-312 .+8} \mathrm{GH}$ fusion gene expression $(\mathrm{rGH}-312)$ relative to that for the ${ }^{-422 .+33}$ PRL construct (rPRL-422) in GC cells; (right) in 235-1 cells, the two values represent the effect of transfecting the reporter plasmid alone or cotransfecting with the Pit-1 expression vector (see Fig. 3A). ( $\square$ ) Reporter gene only; (包) reporter gene plus Pit-1 expression vector. (We were not able to detect a difference between the transfected Pit-1 and the native Pit-1; the two values may be considered replicate estimates of the same value.) (B) RNase protection assay showing the relative amount of Pit-1 mRNA from GC cells to that from 235-1 lactotroph cells. An antisense probe that incorporated the amino-terminal and POU-specific domain coding information of Pit-1 was transcribed with T7 RNA polymerase and produced a probe of 538 nucleotides, of which 355 nucleotides should be protected by mature transcript. Lanes: (Probe) Input probe; $(G C)$ protected probe using RNA from GC cells; $(235-1)$ protected probe using RNA from 235-1 cells; (Markers) the BRL 1-kb ladder. (C) A comparison by Southwestern assay of GC and 235-1 cell nuclear extracts versus Pit-1 bac. (Left) Probed with the ${ }^{-312 . .+8} \mathrm{GH}$ promoter fragment; (right) probed with the ${ }^{-173 . .+33 \mathrm{PRL}}$ promoter fragment (the PRL probe was $\sim 2 \times$ sp. act. of the GH probe). Lanes: (Markers) Protein standards; (GC-Crude) $70 \mu g$ of GC crude nuclear extract; (GC-PC) $3 \mu \mathrm{g}$ of PC-fractionated GC nuclear extract; (235-1-Crude) $70 \mu \mathrm{g}$ of 235-1 crude nuclear extract; $($ Bact-PC) $6 \mu \mathrm{g}$ of PC-fractionated lysate from bacteria carrying a Pit-1 expression vector; $(\mathrm{HeLa}) 70 \mu \mathrm{g}$ of HeLa cell crude nuclear extract. $(D)$ In vitro transcription analysis of 235-1 nuclear extracts. The indicated PRL and GH promoter constructs were used as templates for in vitro transcription reactions containing $20 \mu \mathrm{l}$ of crude $235-1$ nuclear extract.

al. 1988; Yamamoto et al. 1988), which could result in changes in DNA site preference or in affinities for other proteins with which it interacts potentially to activate or 'squelch' transcription (Ptashne 1988). Exploration of the mechanisms responsible for the restriction of the action of Pit-1 in the intact 235-1 cells, including the mod- 
ification of Pit-1 or the actions of a second, labile inhibitor, are under investigation.

Lufkin and Bancroft (1987) have shown that fusion of GH3 rat pituitary cells with $\mathrm{C} 127$ mouse fibroblast cells stably transfected with constructions that contained PRL $5^{\prime}$ sequences allowed the previously quiescent PRL constructs to be expressed. This was not the case with constructs that contained GH $5^{\prime}$ sequences, suggesting either a factor that stimulates only PRL or a mechanism preventing GH expression. In similar experiments, when pituitary (GH3) and nonpituitary (mouse L-cell fibroblast) cells were fused to create permanent lines, GH gene expression was inhibited (Strobl et al. 1982). These fusion cell lines have been reported to have no immunologically detectable levels of GHF-1 (McCormick et al. 1988); it would be revealing to examine PRL gene expression in these cells and to ascertain more accurately that GHF-1 is actually absent in these cells.

On the basis of the analysis of GH and PRL gene expression in pituitary cells, it appears that the concept of an interconnected network of genes, described most convincingly in Drosophila and C. elegans (Scott and Carroll 1987), also appears to operate in pituitary tissue development. The data presented here argue strongly that Pit-1 can regulate the transcription of both the GH and PRL genes, and we predict that the failure to express Pit-1 might result in nonexpression of both GH and PRL in the pituitary gland. The slight differences in affinity between GH and PRL, as determined by footprinting and other binding studies, are obviously not a barrier to transcriptional activation at physiological levels of Pit-1, but activation might be regulated by other factors that modulate the Pit-1 effect. This type of interaction could operate in the inactivation of $\mathrm{GH}$ in the 235-1 lactotroph cell line and is in accord with similar events during Drosophila development.

Our data are consistent with the possibility that Pit-1 is involved in the activation of the developmental programs that generate mature lactotroph and somatotroph phenotypes.

\section{Methods}

\section{Nuclear extract preparation}

GC2 cells were grown in spinner flasks to $8 \times 10^{4} \mathrm{cells} / \mathrm{ml}$ and were concentrated by centrifugation. The cells were washed in ice-cold phosphate buffered saline, pelleted at $1600 \mathrm{~g}$, resuspended in four original cell volumes (OCVs) of buffer $\mathrm{A}$ [10 mM HEPES (pH 7.9 at $1 \mathrm{M}$ ), $10 \mathrm{mM} \mathrm{KCl}, 1.5 \mathrm{~mm} \mathrm{MgCl}_{2}, 1 \mathrm{~mm}$ dithiotreitol (DTT)l, and swelled for $10 \mathrm{~min}$ on ice; they were then centrifuged $\left(1600 \mathrm{~g}, 10 \mathrm{~min}, 4^{\circ} \mathrm{C}\right)$ and resuspended in $2 \mathrm{OCVs}$ of buffer A plus $0.2 \% \mathrm{NP}-40$ and protease inhibitor mix (PIM: 2 mM phenylmethylsulfonyl flouride (PMSF), $1 \mu \mathrm{g} / \mathrm{ml}$ leupeptin, $4 \mathrm{~mm}$ benzamidine, $5 \mathrm{~mm}$ antipain). The cells were allowed to swell for an additional $5 \mathrm{~min}$ and were then disrupted with an iced Dounce B-size glass homogenizer to prepare the nuclei. After 15 strokes, the preparation was examined microscopically for the presence of nuclei, and more strokes were applied until $70-80 \%$ of the preparation was nuclei. The preparation was centrifuged $\left(800 \mathrm{~g}, 10 \mathrm{~min}, 4^{\circ} \mathrm{C}\right)$, and the supernatant was re- moved carefully. The nuclei were resuspended by vortex in 1.2 $\mathrm{ml}$ of buffer C plus PIM $/ \mathrm{ml}$ of OCV. The total volume at this stage was measured and $3 \mathrm{M} \mathrm{KCl}$ was added dropwise to a final concentration of $400 \mathrm{mM} \mathrm{KCl}$, while the preparation was stirred slowly in an ice bath. The extraction continued with slow stirring for $40 \mathrm{~min}$, after which time the preparation was centrifuged $\left(23,000 \mathrm{~g}, 20 \mathrm{~min}, 4^{\circ} \mathrm{C}\right)$ to pellet the nuclei, DNA, and cytoplasmic debris. The supernatant was dialyzed against two changes of $20 \mathrm{~mm}$ HEPES (pH 7.9 at $1 \mathrm{M}$ ), $20 \%$ glycerol, $50 \mathrm{~mm}$ $\mathrm{KCl}$, and $0.2 \mathrm{mM}$ EDTA for 3-4 hr per change, and precipitate was removed by centrifugation $\left(15,000 \mathrm{~g}, 15 \mathrm{~min}, 4^{\circ} \mathrm{C}\right)$. The protein concentration was determined as per Bradford (1976), and the extract was frozen at $-80^{\circ} \mathrm{C}$ in $30-\mathrm{ml}$ vials.

\section{Southwestern protocol}

The Southwestern protocol was modified from Bowen et al. (1980) and Jack et al. (1982).

Crude nuclear extracts or column fractions were concentrated by acetone precipitation ( 2 volumes at $-20^{\circ} \mathrm{C}, 30 \mathrm{~min}$ on ice), followed by centrifugation $\left(15,000 \mathrm{~g}, 7 \mathrm{~min}, 4^{\circ} \mathrm{C}\right)$. The protein pellets were resuspended in SDS-loading dye and boiled for $3 \mathrm{~min}$ before loading on an SDS-polyacrylamide discontinuous gel system (Laemmli 1970). The samples were electrophoresed until the buffer boundary had reached the bottom of the gel. The separated proteins were transferred to nitrocellulose (NC) in transfer buffer [TB: $40 \mathrm{~mm}$ glycine, $50 \mathrm{~mm}$ Tris $[\mathrm{pH}$ not adjusted), $0.04 \%$ SDS, $20 \%$ methanol], using an LKB Electrophor electrotransfer apparatus at $1 \mathrm{~mA} / \mathrm{cm}^{2} \mathrm{NC}$ for $1 \mathrm{hr}$. After the transfer was complete, the NC filter was soaked (1) in $6 \mathrm{M}$ guanidine for $5 \mathrm{~min}$ to denature the proteins completely, (2) in binding buffer [BB: 10\% glycerol, $20 \mathrm{mM}$ HEPES (pH 7.9 at 1 M), $50 \mathrm{mM} \mathrm{KCl}, 1 \mathrm{mM} \mathrm{DTT}, 0.01 \% \mathrm{NP}-40$ ] for $5 \mathrm{~min}$ to renature the protein, and $(3)$ in $5 \%$ Carnation nonfat dry milk in BB for 5 min to block the NC. The excess milk was rinsed-off in BB, and the NC filter was inserted into a polyethylene 'Seal-a-meal' bag with $1 \mathrm{ml} / 10 \mathrm{~cm}^{2}$ probing solution that contained $5 \times 10^{5}$ $\mathrm{cpm} / \mathrm{ml}$ 32P-labeled probe DNA, either in the presence $3-5$ $\mu \mathrm{g} / \mathrm{ml}$ ) or absence of nonspecific [poly $(\mathrm{d} \mathrm{I} / \mathrm{dC}$ ) or salmon sperm] DNA. After probing for at least $3 \mathrm{hr}$ at $4^{\circ} \mathrm{C}$ on a rotating wheel, the filter was removed from the bag, washed in several changes of BB for up to $3 \mathrm{hr}$, blotted dry, covered with Saran Wrap, and put under film with an intensifying screen.

\section{Purification of Pit-1}

All procedures were carried out in a $4^{\circ} \mathrm{C}$ cold room. Nuclear extracts of GC2 cells (see above), were applied to a phosphocellulose (PC; Whatman P11) column equilibrated in $50 \mathrm{mM} \mathrm{KCl}$ PC buffer [ $10 \%$ glycerol, $20 \mathrm{mM}$ HEPES (pH 7.9 at $1 \mathrm{M}$ ), $1 \mathrm{~mm}$ DTT, 2 mM EDTA, 2 mM PMSF, 0.1\% NP-40]. After washing the resin with 2 column volumes of $200 \mathrm{mM} \mathrm{KCl} \mathrm{PC} \mathrm{buffer,} \mathrm{the}$ column was developed with a linear gradient to $700 \mathrm{mM} \mathrm{KCl}$, in a total of 6 column volumes, adjusting the fraction size to yield $\sim 30$ fractions. The active fractions that eluted between 250 and $400 \mathrm{mM} \mathrm{KCl}$ were pooled. $\mathrm{MgCl}_{2}$ was added to $2 \mathrm{mM}$ to titrate the EDTA, and the pooled eluate was applied to a column of hydroxyl apatite (Bio-Gel-HTP, Bio-Rad). Most of the Pit-1 activity flowed through the column, was pooled with 3 column volumes of PC buffer wash, and was diluted sixfold in PC buffer minus $\mathrm{KCl}$ and applied directly /without addition of nonspecific DNA) to the DNA-affinity column made from multimers of the rat GH proximal Pit-1 site $\mid \mathrm{GH} 1$ in Fig. 1A| attached covalently to Sepharose CL6B (Pharmacia), as described by Kadonaga and Tjian (1986). After washing with 2 column volumes of $150 \mathrm{mM} \mathrm{KCl}$, the activity was eluted with a linear gradient 
to $700 \mathrm{mM} \mathrm{KCl}$ in PC buffer. In two instances, the active fractions were pooled and reapplied to the affinity column and eluted as described; but as this did not yield a substantially greater purification, it was not repeated.

\section{DNase I footprinting}

Crude nuclear extract or purified fractions were incubated with a double-stranded DNA probe (10-30 fmoles/reaction; single end-labeled on the $5^{\prime}$ end with $\left[\gamma^{-32} \mathrm{P} \mid \mathrm{ATP}\right.$ or on the $3^{\prime}$ end with $\left.\left[\alpha-{ }^{32} \mathrm{P}\right] \mathrm{dCTP}\right\}$ for $15-30 \mathrm{~min}$ at room temperature in an $\left.80-\mu\right]$ reaction that contained $20 \mathrm{mM}$ HEPES $(\mathrm{pH} 7.9$ at $1 \mathrm{M}), 2 \mathrm{~mm}$ DTT, 2 mM EDTA, and 5\% glycerol. DNase I /Worthington, grade DP) was added to a final concentration of $0.1-5.0 \mu \mathrm{g} / \mathrm{ml}$ in a buffer that contained $70 \mathrm{mM} \mathrm{MgCl}$ and was stopped after 2 min by the addition of $70 \mu \mathrm{l}$ of $1 \%$ SDS, $50 \mathrm{mM}$ EDTA, and 200 $\mu \mathrm{g} / \mathrm{ml}$ yeast tRNA. The sample was extracted with phenol/ chloroform, ethanol-precipitated, centrifuged $(15,000 \mathrm{~g}, 10 \mathrm{~min})$, washed twice with $70 \% \mathrm{ETOH}$, dried over $80^{\circ} \mathrm{C}$ water, resuspended in $95 \%$ formamide loading dyes, and boiled for $3 \mathrm{~min}$. The samples were electrophoresed at $1000-1300$ volts in $1 / 2 \times$ $\mathrm{TBE}$, on a $0.4-\mathrm{mm}$ thick, $7 \%$ polyacrylamide, $8 \mathrm{M}$ urea sequencing gel for $2-4 \mathrm{hr}$ (depending on the probe used), dried, and exposed to film at $-70^{\circ} \mathrm{C}$.

\section{Constructions and tissue culture}

The detailed structure of the SV40/DHFR-based expression vector is described in Lin et al. (1987) and Nelson et al. (1988). The Pit-1 expression vector was constructed from the above vector as described in Ingraham et al. (1988). The HeLa/Pitl ${ }^{+}$ stable cell lines were generated by a modification of the classical method (Southern and Berg 1982) of transfecting $10^{6} \mathrm{HeLa}$ cells with $10 \mu \mathrm{g}$ of the SV40-based Pit-1 expression plasmid via the $\mathrm{CaPO}_{4}$ coprecipitaion method (Chen and Okayama 1987). After 2 days, the cells were put under methotrxate selection ( $800 \mathrm{nM})$ and amplified by increasing methotrexate concentrations in stages of 5 days $(800,1200,2500,5000 \mathrm{nM})$. Resistant colonies were cloned and maintained under methotrexate selection (400 nM) in Dulbecco's modified Eagle's medium (DMEM).

Transfection of PRL-luciferase and GH-luciferase plasmids (Nelson et al. 1988) into the $\mathrm{HeLa} / \mathrm{Pitl}^{+}{ }^{+}$cells also was effected by the $\mathrm{CaPO}_{4}$ coprecipitation method, using $10 \mu \mathrm{g}$ plasmid/106 cells in an $8-\mathrm{cm}$ plate. Forty-eight hours after transfection, the cells were washed with $3 \mathrm{ml}$ of Tris-buffered saline and harvested by scraping in $1 \mathrm{ml}$ of $50 \mathrm{mM}$ HEPES (pH 7.9 at $1 \mathrm{M}$ ), 15 $\mathrm{mM} \mathrm{Mg}$ acetate, and $1 \mathrm{mM}$ DTT. The cells were centrifuged at $500 \mathrm{~g}$ for $2 \mathrm{~min}$, and all but $200 \mu \mathrm{l}$ of the supernatant was aspirated, after which the cell pellets were dispersed by Vortex agitation and the cells were lysed by three cycles of freezing (powdered dry ice) and thawing $\left(37^{\circ} \mathrm{C}\right)$. The particulate debris was pelleted $(13000 \mathrm{~g}, 5 \mathrm{~min})$ and $50 \mu \mathrm{l}$ of the supernatant was assayed for luciferase activity by adding $150 \mu \mathrm{l}$ of freshly prepared $50 \mathrm{mM}$ HEPES ( $\mathrm{pH} 7.9$ at $1 \mathrm{~m}$ ), $15 \mathrm{~mm} \mathrm{Mg}$ acetate, and $4 \mathrm{~mm}$ ATP and reading the light emitted in a Monolight model 2001, which added automatically $100 \mu \mathrm{l}$ of $2 \mathrm{~mm}$ luciferin (Analytical Luminescence Laboratory) and integrated the light peak over 10 sec.

Transfection of GC2 cells and 235-1 cells was performed as a modification of Gorman et al. (1982a). Briefly, $2 \times 10^{6}$ cells $/ 8$ $\mathrm{cm}$ plate were given $7 \mathrm{ml}$ of fresh DMEM (plus serum) $5 \mathrm{hr}$ before the transfection. The media was aspirated, and $10 \mu \mathrm{g}$ of plasmid in $2 \mathrm{ml}$ of media was added to the plate. Immediately afterward, $400 \mu \mathrm{g} / \mathrm{ml}$ of DEAE-dextran in another $2 \mathrm{ml}$ of media was added dropwise to the plate as it was rocked gently.
The transfected cells were returned to the incubator for $2 \mathrm{hr}$, the plasmid/DEAE-dextran media was aspirated and $8 \mathrm{ml}$ of media (plus serum) was added and the cells returned to the incubator. After $48 \mathrm{hr}$, the cells were harvested and assayed as described for the HeLa cells, above.

\section{RNase protection assays}

RNA was isolated, poly(A)-selected from 235-1 cells as described previously (Ingraham et al. 1988), and subjected to RNase protection analysis as described (He et al. 1989). Briefly, a clone that contained Pit- 1 cDNA extending $3^{\prime}$ to a portion of the POU domain in pBKS (Stratagene) was used to generate labeled antisense probe, using T7 RNA polymerase in the presence of [ $\left.{ }^{32} \mathrm{P}\right] \mathrm{UTP}(>800 \mathrm{Ci} / \mathrm{mmole})$, that generated an RNA transcript of 538 nucleotides. RNA from $235-1$ cells $(20 \mu \mathrm{g})$ was hybridized to $5 \times 10^{5} \mathrm{cpm}$ antisense probe (heated to $85^{\circ} \mathrm{C}$ and annealed for $12 \mathrm{hr}$ at $45^{\circ} \mathrm{C}$ ) and digested with RNase A (30 $\mu \mathrm{g} / \mathrm{ml}$ ) at $30^{\circ} \mathrm{C}$ for $45 \mathrm{~min}$ prior to electrophoresis on a sequencing gel. Markers used were the BRL 1-kb standard ladder.

\section{Acknowledgments}

We thank Rouping Chen for her contributions in the preparation of Pit-1 expression vectors, Dr. Charles Prussak for advice in protein purification, and Drs. Stuart Adler, Maurice Treacy, Chris Glass, Dan Drolet, and other members of the Rosenfeld lab for much helpful discussion and criticism. In addition, we thank Drs. Marian Waterman and Kathy Jones for their helpful discussion. We also appreciate the assistance of Bob Fleischaker and Vista Biologicals (Vista, California) for the preparation of the cell cultures.

\section{References}

Awgulewitsch, A., M.F. Utset, C.P. Hart, W. McGinnis, and F.H. Ruddle. 1986. Spatial restriction in expression of a mouse homeobox locus within the central nervous system. Nature 320: 328-335.

Behringer, R.R., L.S. Mathews, R.D. Palmiter, and R.L. Brinster. 1988. Dwarf mice produced by genetic ablation of growth hormone-expressing cells. Genes Dev. 2: 453-460.

Bodner, M. and M. Karin. 1987. A pituitary-specific trans-acting factor can stumulate transcription from the growth hormone promoter in extracts of nonexpressing cells. Cell 50: 267-275.

Bodner, M., J.L. Castrillo, L.E. Theill, T. Deerinck, M. Ellisman, and $M$. Karin. 1988. The pituitary-specific transcription factor GHF-1 is a homeobox-containing protein. Cell 55: 505-518.

Bowen, B., J. Steinberg, U.K. Laemmli, and H. Weintraub. 1980. The detection of DNA-binding protein by protein blotting. Nucleic Acids Res. 8: 1-8.

Bradford, M.M. 1976. A rapid and sensitive method for the quantitation of microgram quantities of protein utilizing the principle of protein-dye binding. Anal. Biochem. 72: 248254.

Cao, Z., E.A. Barron, and Z.D. Sharp. 1988. Prolactin upstream factor I mediates cell-specific transcription. Mol. Cell Biol. 8: $5432-5438$.

Cao, Z., E.A. Barron, A.J. Carrillo, and Z.D. Sharp. 1987. Reconstitution of cell-type-specific transcription of the rat prolactin gene in vitro. Mol. Cell Biol. 7: 3402-3408.

Carrasco, A.E., W. McGinnis, W.J. Gehring, and E.M. De Robertis. 1984. Cloning of a $X$. laevis gene expressed during 
early embryogenesis that codes for a peptide region homologous to Drosophila homeotic genes. Cell 37: 409-414.

Castrillo, J.-L., M. Bodner, and M. Karin. 1989. Purification of growth hormone-specific transcription factor GHF-1 containing homeobox. Science 243: 814-817.

Chalfie, M., H.R. Horvitz, and J. Sulston. 1981. Mutations that lead to reiterations in the cell lineages of C. elegans. Cell 24: 59-69.

Chatelain, A., J.P. Dupuoy, and M.P. Dubois. 1979. Ontogenesis of cells producing polypeptide hormones in the fetal hypophysis of the rats: Influence of the hypothalamus. Cell Tiss. Res. 196: 409-427.

Chen, C. and H. Okayama. 1987. High efficiency transformation of mammalian cells by plasmid DNA. Mol. Cell. Biol. 7: $2745-2752$.

Clerc, R.G., L.M. Corcoran, J.H. LeBowitz, D. Baltimore, and P.A. Sharp. 1988. The B-cell specific Oct-2 protein contains POU box and homeo box-type domains. Genes Dev. 2: $1570-1581$.

Colberg-Poley, A.M., S.D. Voss, K. Chowdhury, and P. Gruss. 1985. Structural analysis of murine genes containing homeobox sequences and their expression in embryonal carcinoma cells. Nature 314: 713-718.

Cooke, N.E., D. Coit, R.I. Weiner, J.D. Baxter, and J.A. Martial. 1981. Human prolactin: Structural analysis and evolutionary comparisons. J. Biol. Chem. 256: 4007-4016.

Costa, R.H., D.R. Grayson, K.G. Xanthopoulos, and J.E. Darnell. 1988. A liver-specific DNA binding protein recognizes multiple nucleotide sites in regulatory regions of transthyretin, $\alpha$ l-antitrypsin, albumin, and simian vinus 40 genes. Proc. Natl. Acad Sci. 85: 3840-3844.

Crenshaw III, E.B., K. Kalla, D.W. Simmons, L.W. Swanson, and M.G. Rosenfeld. 1989. Cell-specific expression of the prolactin gene in transgenic mice is controlled by synergistic interactions between enhancer and promoter elements. Genes Dev. 3: 959-972.

Desplan, C., J. Theis, and P.H. O'Farrell. 1988. The sequence specificity of homeodomain-DNA interaction. Cell 54: $1081-1090$.

De Wet, J.R., K.V. Wodd, M. Deluca, D.R. Helinski, and S. Subramani. 1987. Firefly luciferase gene: Structure and expression in mammalian cells. Mol. Cell. Biol. 7: 725-737.

Finney, M., G. Ruvkun, and H.R. Horvitz. 1988. The C. elegans cell lineage and differentiation gene unc 86 encodes a protein containing a homeodomain and extended sequence similarity to mammalian transcription factors. Cell 55: 757769.

Fried, M. and D. Crothers. 1983. CAP and RNA polymerase interactions with the lac promoters: Binding stoichiometry and long range effects. Nucleic Acids Res. 11: 141-158.

Galas, D.J. and A. Schmitz. 1978. DNAse footprinting: A simple method for the detection of protein-DNA binding specificity. Nucleic Acids Res. 5: 3157-3170.

Gehring, W.J. 1987. Homeoboxes in the study of development. Science 236: 1245-1252.

Glass, C.K., R. Franco, C. Weinberger, V.R. Albert, R.M. Evans, and M.G. Rosenfeld. 1987. A c-erb A binding site in the rat growth hormone gene mediates transactivation by thyroid hormone. Nature 329: 738-741.

Gorman, C.M., L.F. Moffat, and B.H. Howard. 1982a. Recombinant genomes which express chloramphenicol acetyltransferase in mammalian cells. Mol. Cell. Biol. 2: 1044-1051.

Gorman, C.M., G.T. Merlino, M.C. Willingham, I. Pastan, and B.H. Howard. 1982b. The Rous sarcoma virus long terminal repeat is a strong promoter when introduced into a variety of eukaryotic cells by DNA-mediated transfection. Proc. Natl. Acad. Sci. 79: 6777-6781.

Guitierrez-Hartmann, A., S. Siddiqui, and S. Loukin. 1987. Selective transcription and DNase I protection of the rat prolactin gene by GH3 pituitary cell-free extracts. Proc. Natl. Acad. Sci. 84: 5211-5215.

Hammer, R.E., G.H. Swift, D.M. Ornitz, C.J. Quaife, R.D. Palmiter, R.L. Brinster, and R.J. MacDonald. 1987. The rat elastase 1 regulatory element is an enhancer that directs correct cell specificity and developmental onset of expression in transgenic mice. Mol. Cell Biol. 7: 2956-2967.

He, X., M.N. Treacy, D.M. Simmons, H.A. Ingraham, L.W. Swanson, and M.G. Rosenfeld. 1989. Expression of a large family of POU-domain regulatory genes in mammalian brain development. Nature, (in press).

Herr, W., R.A. Sturm, R.G. Clerc, L.M. Corcoran, D. Baltimore, P.A. Sharp, H.A. Ingraham, M.G. Rosenfeld, M. Finney, G. Ruvkun, and H.R. Horvitz. 1988. The POU domain: A large conserved region in the mammalian Pit-1, Oct-1, Oct-2, and Caenorhabditis elegans unc-86 gene products. Genes Dev. 2: $1513-1516$.

Hoeffler, J.P, F.R. Boockfor, and L.S. Frawley. 1985. Ontogeny of prolactin cells in neonatal rats: Initial prolactin secretors also release growth hormone. Endocrinology 117: 187-195.

Hoey, T. and M. Levine. 1988. Divergent homeo box proteins recognize similar DNA sequences in Drosophila. Nature 332: $858-861$

Ingraham, H.A, R. Chen, H.J. Mangalam, H.P. Elsholtz, S.E. Flynn, C.R. Lin, D.M. Simmons, L. Swanson, and M.G. Rosenfeld. 1988. A tissue-specific transcription factor containing a homeodomain specifies a pituitary phenotype. Cell 55: 519-529.

Jack, R.S., M.T. Brown, and W.J. Gehring. 1982. Protein blotting as a means to detect sequence-specific DNA-binding proteins. Cold Spring Harbor Symp. Quant. Biol. 68: 483-491.

Jackson, S.P. and R. Tjian. 1988. O-Glycosylation of eukaryotic transcription factors: Implications for mechanisms of transcriptional regulation. Cell 55: 125-133.

Kadonaga, J.T. and R. Tjian. 1986. Affinity purification of sequence-specific DNA binding proteins. Proc. Natl. Acad. Sci. 83: 5889-5893.

Ko, H.-S., P. Fast, W. McBride, and L.M. Staudt. 1988. A human protein specific for the immunoglobulin octamer DNA motif contains a functional homeobox domain. Cell 55: $135-144$.

Laemmli, U.K. 1970. Cleavage of structural proteins during the assembly of the the head of the bacteriophage T4. Nature 227: 680-685.

Levine, M. and T. Hoey. 1988. Homeobox proteins as sequencespecific transcription factors. Cell 55: 537-540.

Lin, C.R., M.S. Kapiloff, S. Durgerian, K. Tatemoto, A.F. Russo, P. Hanson, H. Schulman, and M.G. Rosenfeld. 1987. Molecular cloning of a brain-specific calcium/calmodulin-dependent protein kinase. Proc. Nat1. Acad. Sci. 84: 5962-5966.

Lira, S.A., E.B. Crenshaw III, C.K. Glass, L.W. Swanson, and M.G. Rosenfeld. 1988. Identification of rat growth hormone genomic sequences targeting pituitary expression in transgenic mice. Proc. Natl. Acad. Sci. 85: 4755-4759.

Lufkin, T. and C. Bancroft. 1987. Identification by cell fusion of gene sequences that interact with positive trans-acting factors. Science 237: 283-286.

Manley, J.L. and M.S. Levine. 1985. The homeo box and mammalian development. Cell 43: 1-2.

McCormick, A., D. Wu, J.-L. Castrillo, S. Dana, J. Strobl, E.B. Thompson, and M. Karin. 1988. Extinction of growth hor- 
mone expression in somatic cell hybrids involves repression of the specific trans-activator GHF-1. Cell 55: 379-389.

McGinnis, W., R.L. Garber, J. Wirz, A. Kuroiwa, and W.J. Gehring. 1984. A homologous protein-coding sequence in Drosophila homoeotic genes and its conservation in other metazoans. Cell 37: 403-408.

Merril, C.R., D. Goldman, and M.L. Van Keuren. 1984. Gel protein stains: Silver stain. Methods Enzymol. 104: 441-447.

Montminy, M.R., K.A. Sevarino, J.A. Wagner, G. Mandel, and R.H. Goodman. 1986. Identification of a cyclic-AMP-responsive element within the rat somatostatin gene. Proc. Natl. Acad. Sci. 83: 6682-6686.

Muller, M.M., S. Ruppert, W. Schaffner, and P. Matthias. 1988. A cloned octamer transcription factor stimulates transcription from lymphoid-specific promoters in non-B cells. $\mathrm{Na}$ ture 336: 544-551.

Nelson, C., V.R. Albert, H.P. Elsholtz, L.E.-W. Lu, and M.G. Rosenfeld. 1988. Activation of cell-specific expression of rat growth hormone and prolactin genes by a common transcription factor. Science 239: 1400-14405.

Nelson, C., E.B. Crenshaw III, R. Franco, S.A. Lira, V.R. Albert, R.M. Evans, and M.G. Rosenfeld. 1986. Discrete cis-active genomic sequences dictate the pituitary cell type-specific expression in rat prolactin and growth hormone genes. $\mathrm{Na}$ ture 322: 557-562.

Ptashne, M. 1988. How eukaryotic transcriptional activators work. Nature 335: 683-689.

Rosenberg, A.H., B.N. Lade, D.S. Chui, S.W. Lin, J.J. Dunn, and F.W. Studier. 1987. Vectors for selective expression of cloned DNAs by T7 RNA polymerase. Gene 56: 125-135.

Santoro, C., N. Mermod, P.C. Andrews, and R. Tjian. 1988. A family of human CCAAT-box-binding proteins active in transcription and DNA replication: Cloning and expression of multiple cDNAs. Nature 334: 218-224.

Scott, M.P. and S.B. Carroll. 1987. The segmentation and homeotic gene network in early Drosophila development. Cell 51: 689-698.

Sen, R. and D. Baltimore. 1986. Multiple nuclear factors interact with the immunoglobulin enhancer sequences. Cell 46: $705-716$.

Shephard, J.C.W., W. McGinnis, A.E. Carrasco, E.M. DeRobertis, and W.J. Gehring. 1984. Fly and frog homeodomains show homologies with yeast mating type regulatory proteins. Nature 310: 70-71.

Sive, H.L. and R.G. Roeder. 1986. Interaction of a common factor with conserved promoter and enhancer sequences in histone $\mathrm{H} 2 \mathrm{~B}$, immunoglobulin, and U2 small nuclear RNA (snRNA) genes. Proc. Natl. Acad. Sci. 83: 6382-6386.

Southern, P.J. and P. Berg. 1982. Transformation of mammalian cells to antibiotic resistance with a bacterial gene under control of the sv40 early region promoter. $/$. Mol. Appl. Genet. 1: 327-341.

Staudt, L.M., H. Singh, R. Sen, T. Wirth, P.A. Sharp, and D. Baltimore. 1986. A lymphoid-specific protein binding to the octomer motif of immunoglobulin genes. Nature 323: 640643.

Strobl, J.S., P.S. Dannies, and E.B. Thompson. 1982. Somatic cell hybridization of growth hormone-producing rat pituitary cells and mouse fibroblasts results in extinction of growth hormone expression via a defect in growth hormone RNA production. J. Biol. Chem. 257: 640-643.

Studier, F.W. and B.A. Moffat. 1986. Use of Bacteriophage. T7 RNA polymerase to direct selective high-level expression of cloned genes. I. Mol. Biol. 189: 13-130.

Sturm, R.A. and W. Herr. 1988. The POU domain is a bipartite DNA-binding structure. Nature 336: 601-604.
Sturm, R.A., G. Das, and W. Herr. 1988. The ubiquitous octamer binding protein Oct-1 contains a POU domain with a homeo box subdomain. Genes Dev. 2: 1582-1599.

Walker, M., T. Edlund, A.M. Boulet, and W.J. Rutter. 1983. Cell-specific expression controlled by the $5^{\prime}$-flanking region of insulin and chymotrypsin genes. Nature 306: 557-561.

Watanabe, Y.G. and S. Daikoku. 1979. An immunohistochemical study on the cytogenesis of adenohypophysial cells in fetal rats. Dev. Biol. 68: 557-567.

West, B.L., D.F. Catanzaro, S.H. Mellon, P.A. Cattini, J.D. Baxter, and T. L. Reudelhuber. 1987. Interaction of a tissuespecific factor with an essential rat growth hormone gene promoter element. Mol. Cell. Biol. 7: 1193-1197.

Yamamoto, K.K., G.A. Gonzalez, W.H. Biggs III, and M.R. Montminy. 1988. Phosphorylation-induced binding and transcriptional efficacy of nuclear factor CREB. Nature 334: 494-498.

Yamamoto, K.R. 1985. Steroid receptor regulated transcription of specific genes and gene networks. Annu. Rev. Genet. 19: $209-252$.

Ye, Z.S. and H.H. Samuels. 1987. Cell- and sequence-specific binding of nuclear proteins to $5^{\prime}$-flanking DNA of the rat growth hormone gene. I. Biol. Chem. 262: 6313-6317. 


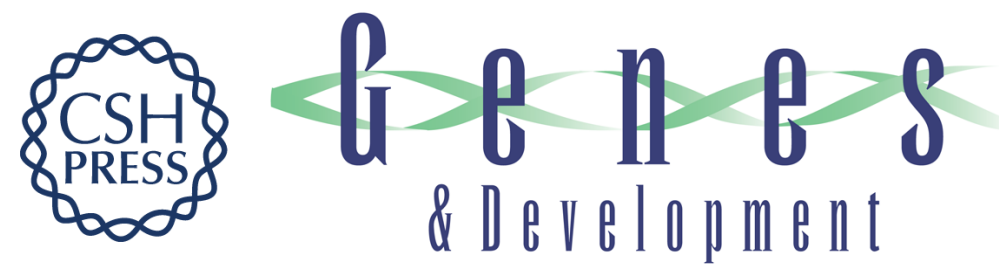

\section{A pituitary POU domain protein, Pit-1, activates both growth hormone and prolactin promoters transcriptionally.}

H J Mangalam, V R Albert, H A Ingraham, et al.

Genes Dev. 1989, 3:

Access the most recent version at doi:10.1101/gad.3.7.946

References This article cites 69 articles, 26 of which can be accessed free at:

http://genesdev.cshlp.org/content/3/7/946.full.html\#ref-list-1

License

Email Alerting

Service

Receive free email alerts when new articles cite this article - sign up in the box at the top right corner of the article or click here.

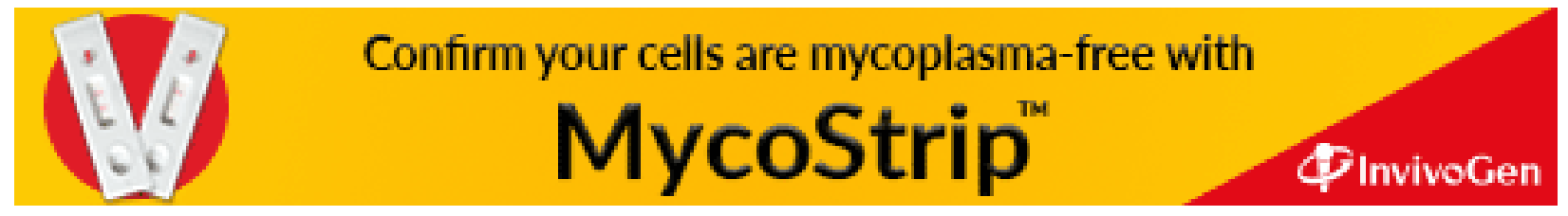

